\title{
Dreiländertreffen 2022
}

Vom 29.06.-01.07.2022 findet an der ETH Zürich das nächste Dreiländertreffen Sonografie statt. Geplant ist ein hybrider Kongress mit viel praktischer Übungszeit in einer Vielzahl von „Sonohöhlen“ für die Teilnehmenden vor Ort. Einen besonderen Fokus legen wir auch auf den studentischen Ultraschall.
Weitere Informationen unter www.ultraschall2022.ch. 